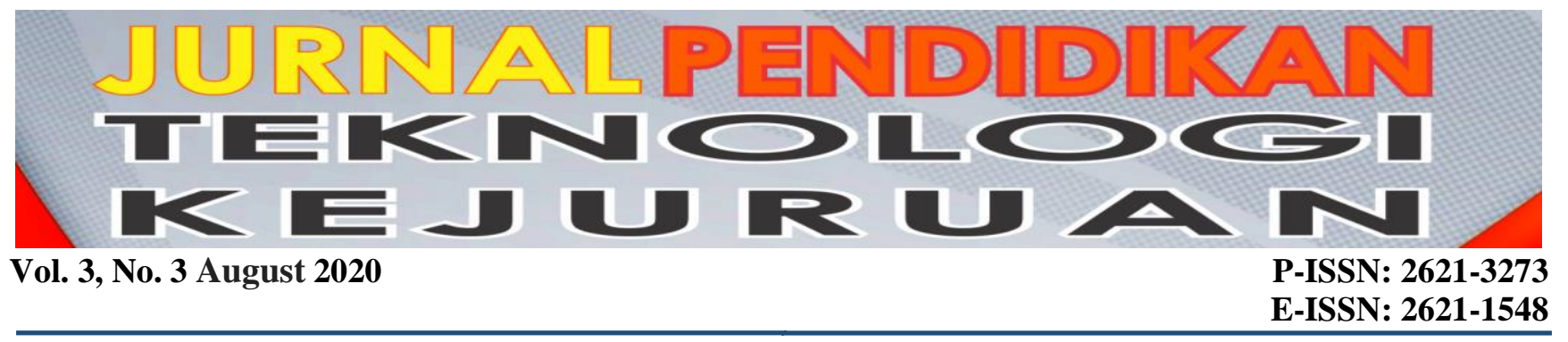

\title{
Improvement of the Concept of Mitosis Instruction to Improve Biological Achievement Among Secondary School Students
}

\author{
Akawo Angwal Yaki ${ }^{1}$, Koroka Mohammed Sanda ${ }^{2}$, Rabiu Mohammad Bello \\ 1,2,3 Department of Science Education, Federal University of Technology, MinnaNiger State, Nigeria \\ *Corresponding author, e-mail: m.koroka@ futminna.edu.ng
}

\begin{abstract}
The study examined the effects of Improvised Instructional Material Enhanced Biology Achievement among Secondary School Students in Lapai, Niger State. Quasi-experimental design which involved pretest, posttest, experimental and control group. A total of eight five (85) Senior Secondary two (SSII) students randomly selected from two sampled schools formed the sample size of the study. The instrument used for data collection was a researchers' designed Biology Achievement Test (BAT). The instrument was validated, and pilot tested and yielded a reliability coefficient of 0.75 . Two research questions were raised, and two corresponding null hypotheses were formulated to guide the study, the null hypotheses were tested at 0.05 level of significant. The result of the study showed among others a significant difference in achievement score of the experimental and control groups in favor of the experimental group. The finding also showed that both male and female students' achievements were enhanced equally. It was recommended among others that Biology teachers should be encouraged to improvise instructional materials for effective teaching and learning of Biology.
\end{abstract}

Keyword: Biology, Improvisation, Instructional Materials, Mitosis and Students' Achievement.

Copyright () 2020 JPTK. All rights reserved

\section{INTRODUCTION}

Success or failure of every nation lies on the level of educational advancement of her citizenry. This implies that for any nation to attain and sustain national development, a well-planned, and implemented educational policy must be given proper attention by the government of that nation. Government must see education especially science and technology as an essential tool for her national development. According to Umoru (2016), knowledge of science is believed to be of paramount importance as it explains the structure and functions of living things in our environment and how to improve on our way of living. Sheldon (2011) define science as an intellectual activity designed by humans to discover information about the natural world in which humans live and to discover the ways this information can be organized into meaningful patterns for human satisfaction. Science comprises of basic subjects like Chemistry, Physics, Mathematics and Biology.

Biology is a branch of science that deals with the study of living organisms and the interdependent relationship between living organisms and their immediate environments. Sarigin (2010) on the other hand sees Biology as a fascinating study that ranges from microscopic cellular molecules to the biosphere, encompassing the earth surface and its biotic components. Biology is broad in scope and can be broken down into several specialized subbranches like Anatomy, Cell Biology, Genetics, Physiology, Ecology, Evolution just to mention a few. This is one of the reasons why Biology is introduced to students at senior secondary school level of Nigerian educational system as a preparatory ground for human development, where career abilities are groomed, potentials and talents are discovered and energized (FRN, 2009). This is because Biology is a prerequisite subject for the study of some professional courses such as medicine, pharmacy, veterinary medicine, agriculture, and many others. Hence, biology is a very important subject for national development.

Considering the high value given to Biology in the Nigerian secondary school curriculum, the need to teach it effectively through an effective method is indispensable. Research studies have shown that there is an increased enrolment of students in 
Biology yearly but the students' achievement at the Senior School Certificate Examinations (SSCE) conducted by the West African Examinations Council (WAEC) and National Examination Council (NECO) is not encouraging(Lawal, 2014 \& WAEC, 2016). Many reasons have been advanced for the poor performance of biology students by different researchers. Some of the advanced reasons include inadequate instructional material, lack of qualified teachers and poor instructional strategies employed by some teachers, abstractness, or difficult nature of some Biology concepts among others (Ahmed, 2010). Some of the abstract or difficult concepts of Biology include Evolution, Genetics, Osmosis, Mitosis and Meiosis. These concepts cannot be effectively taught without the use of relevant instructional materials.

Instructional materials are those channels of communication which promote the effectiveness of instruction and help the teacher to communicate ideas effectively to his student (Ali, 2012). Instructional materials include all the substantial resources that a teacher can use to implement instruction which facilitates students' achievement at the final SSCE Examinations. It should be noted that it is not all lessons or topics that can be effectively taught without the use of instructional material (Olumorin,Yusuf, Ajidagba \& Jekayinfa,2010).According to Awolaju (2015), Instructional materials play a key role in concretizing learning of science in general. Instructional materials make learning meaningful and help to improve students' level of comprehension of the abstract or difficult concepts. According to Umoru (2016), instructional material enhances, facilitate, and make teaching and learning lively and concrete.

Awolaju (2015) conducted a research study on instructional materials as a correlation of Biology students academic performance in Osun state, Nigeria. The researcher used stratified and simple random sampling to sample a total of 100 students (50\% males, 50\% female) for the study. A 30-items test instrument with four options multiple choice named Biology Achievement Test (BAT) was used for data collection. The result of the study revealed a significant difference in academic performance of the students taught Biology using instructional materials and those taught using conventional method. Also Adeyemi and Olayeye (2010) investigated the effect of student involvement in production of instructional material on their academic performance in Biology and they reported that a significant difference existed between students taught biology without instructional materials and those taught using locally produced instructional materials.

Studies on the poor achievement among biology students at secondary school level shows that, the use of instructional materials help students achieve higher as compared to the conventional teaching method (Abdulrahman, 2016\& Awolaju, 2015). Isola (2010) reported that students taught reproduction in biology with constructive strategy achieved higher than those taught using conventional method. It was also reported to be gender friendly. Study by Ogunleye and Babajide (2011) shows no significant effects of gender in science. Other researchers asserted that gender influences students' achievement in science (Adeyemi \& Olaleye, 2010 \&Eze, 2012,) in favour of female students. From the foregoing statement it is agreed that instructional materials are an essential tool for enhancing students' achievement and that, gender disparity in education is inconclusive.

However, these advantages of instructional materials have not reflected at the secondary schools' level of Nigeria education system because of the shortage of these instructional materials. This is because Nigerian economy at present does not warrant the provision of all instructional materials that the school needs. This informed the idea of using available local materials in place of the real instructional materials to ensure that teaching and learning takes place without hinges. The use of available local materials to produce instructional materials in the absence of the original instructional materials is referred to as improvisation. It is therefore, the responsibility of the Biology teachers to improvise instructional materials in the absence of the real instruction materials during classroom instruction.

The traditional method of instruction which is predominant in Nigeria is teacher centred while the students are passive in the learning process which has resulted in poor performance of students in biology. Assessment in the traditional environment focused on memorization and lower thinking skills as against higher order thinking skills needed in the

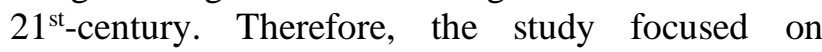
enhancing biology achievement using improvised instructional material among secondary school students

\section{Aim and Objectives of the Study}

The aim of the study is to determine enhancing biology achievement using improvised instructional material among secondary school students. The specific objectives to be achieved include;

1. the difference in mean achievement score of students taught the concept of Mitosis in Biology 
using improvised phases of mitosis and those taught with conventional instructional method.

2. the gender difference in mean achievement score of students taught the concept of Mitosis in Biology with improvised phases of mitosis.

\section{Research Questions}

The following research questions were raised and answered using Mean and Standard Deviation

1. does the use of improvised instructional material (improvised phases of Mitosis) in teaching the concept of Mitosis in Biology enhance secondary school students' mean achievement score?

2. does the use of improvised instructional material (improvised phases of mitosis) in teaching the concept of Mitosis in Biology enhance secondary school students' mean achievement score based on gender?

\section{Research hypotheses}

The following null hypotheses were formulated and tested at 0.05 level of significant:

$\mathrm{HO}_{1}$ : There is no significant difference in the mean achievement score of Biology students taught the concept of Mitosis with improvised instructional material (improvised phases of mitosis) and those taught with conventional instructional method.

$\mathrm{HO}_{2}$ : There is no significant gender difference in the mean achievement score of Biology students taught the concept of Mitosis with improvised instructional material (improvised phases of mitosis)

\section{METHOD}

The research design used for the study is Quasiexperimental design involving pretest, posttest, experimental and control group. The choice of this design was to avoid interference with the school time-table therefore, intact classes were used for the study. The total population of biology student in Lapai Niger State was 3,226, The target population (SSII Biology students) was 1,425. Sample size used for this study was 85 students. The students were drawn from two intact classes of two co-educational schools randomly sampled for the study. A simple random sampling technique was used to select two co-educational secondary schools in Lapai, Niger State. The schools were randomly assigned to experimental and control groups. The experimental group consists of 45 students and was taught with instructional material (improvised phases of mitosis). Control group on the other hand consists of 40 students and was taught without instructional materials (improvised phases of mitosis).

Two different instruments used for the study are: (i) Test instrument and (ii) Treatment instrument. Test instrument was Biology Achievement Test (BAT)developed by the researchers based on SS II Biology curriculum on the concept of mitosis. BAT contains twenty (20) questions each with four options (A-D) and only one of the options is correct. The face and content validity of the instrument was conducted by three experts. The BAT was pilot tested and reliability of 0.75 was obtained using test-retest technique.BAT was used to collect data as pretest and posttest from both experimental and control groups

Treatment instrument was the instructional material (improvised phase of Mitosis) also developed by the researchers and used on the experimental group while conventional instructional method was used on the control group (without instructional material). Treatment instruments were also validated by experts to determine their appropriateness on the group of students they were developed to be used on. Experimental group students were taught the concept of Mitosis in Biology using improvised instructional material (improvised phase of Mitosis) while the control group students were taught the same concept using conventional teaching method (without instructional materials). At the end of the treatment, Biology Achievement Test BAT was administered on the students of both groups. The data obtained (pretest and posttest scores) from the study were analyzed using mean, standard deviation and t-test statistic.

\section{RESULT}

\begin{tabular}{|c|c|c|c|c|c|c|c|}
\hline \multicolumn{8}{|c|}{$\begin{array}{l}\text { Pretest Result } \\
\text { Tale 1: Mean and Standard Deviation of Pretest } \\
\text { Score of Experimental and Control Groups }\end{array}$} \\
\hline Group & Group & $\mathbf{N}$ & Df & $\overline{\boldsymbol{X}}$ & SD & $\begin{array}{l}\text { t- } \\
\text { valu } \\
\text { e }\end{array}$ & $\begin{array}{l}\text { P- } \\
\text { value }\end{array}$ \\
\hline $\begin{array}{l}\text { Pre- } \\
\text { Test }\end{array}$ & $\begin{array}{l}\text { Experim } \\
\text { ental } \\
\text { Control }\end{array}$ & 45 & 83 & $\begin{array}{l}41.3 \\
3 \\
43.2 \\
5\end{array}$ & $\begin{array}{l}8.55 \\
5 \\
8.59 \\
0 \\
\end{array}$ & 0.77 & $\begin{array}{l}0.12^{\mathrm{N}} \\
\mathrm{s}\end{array}$ \\
\hline
\end{tabular}

Table 1 shows the t-test analysis of pretest of experimental and control group ( $\mathrm{t}$-value $=0.77$, $\mathrm{df}=83, \quad \mathrm{P}$-value $=0.12 \& \mathrm{P}>0.05)$ was not significant. This indicates the students' entry knowledge about Mitosis is equal before the treatment.

Research Question One: Does the use of improvised instructional material (improvised phases of mitosis) in teaching the concept of Mitosis in Biology enhance students mean achievement score? 
Table 2: Mean and Standard Deviation of Achievement Score of Experimental and Control Groups

\begin{tabular}{lccccl}
\hline Group & $\mathrm{N}$ & $\begin{array}{l}\text { Mean } \\
(\bar{X})\end{array}$ & SD & $\begin{array}{l}\text { Mean } \\
\text { Differ } \\
\text { ence }\end{array}$ & Remark \\
\hline $\begin{array}{l}\text { Experimen } \\
\text { tal }\end{array}$ & 45 & 70.22 & 10.44 & 8.34 & $\begin{array}{l}\text { Significa } \\
\text { nt }\end{array}$ \\
Control & 40 & 61.88 & 9.59 & &
\end{tabular}

Table 2 shows Mean achievement score and Standard Deviation of Biology students taught Mitosis using improvised instructional materials and those taught using conventional teaching method. The table revealed that, experimental group had a Mean achievement score of 70.22 with Standard Deviation of 10.44 and control group had Mean achievement score of 61.88 with Standard Deviation of 9.59. The mean difference is 8.34 in favour of the experimental group. This revealed that improvised instructional materials have enhanced the experimental group students' achievement higher than conventional teaching method.

Research Question Two: does the use of improvised instructional material (improvised phases of mitosis) in teaching the concept of Mitosis in Biology enhance students' mean achievement score based on gender?

Table 3: Mean and Standard Deviation of Achievement Score of Male and Female Students in Experimental Group

\begin{tabular}{lcccll}
\hline Gender & $\mathrm{N}$ & $\begin{array}{l}\text { Mean } \\
(\bar{X})\end{array}$ & SD & $\begin{array}{l}\text { Mean } \\
\text { Difference }\end{array}$ & Remark \\
\hline Males & 24 & 66.65 & 10.73 & & Not \\
Females & 21 & 67.05 & 10.98 & & significant \\
\hline
\end{tabular}

Table 3 shows Mean achievement score and Standard Deviation of secondary school Biology male and female students taught Mitosis using improvised instructional materials and those taught using conventional teaching method. The table revealed that male students had Mean achievement score of 66.65 with Standard Deviation of 10.73 and female students had Mean achievement score of 67.05 with Standard Deviation of 10.98. The mean difference is 0.40 in favour of female students, but the difference is not significant. This revealed that improvised instructional materials enhanced both male and female students' achievement equally. The researchers are of the opinion that Mean comparison is not enough to decide whether the above results are significant or not therefore, the formulated null Hypotheses were tested as shown in tables 4 and 5.

\section{Testing of Hypotheses}

Ho1: There is no significant difference in the mean achievement score of Biology students taught the concept of Mitosis with improvised instructional material (improvised phases of mitosis) and those taught with conventional instructional method. To test this formulated hypothesis, independent t-test was used, and the analysis presented in Table 4.

Table 4: t-test Analysis of Mean Achievement Scores of Experimental and Control Groups

\begin{tabular}{|c|c|c|c|c|c|c|c|}
\hline $\begin{array}{l}\text { Grou } \\
\text { p }\end{array}$ & Group & $\mathbf{N}$ & Df & $\overline{\boldsymbol{X}}$ & SD & $\begin{array}{l}\text { t- } \\
\text { valu } \\
\text { e }\end{array}$ & $\begin{array}{l}\text { P- } \\
\text { valu } \\
\text { e }\end{array}$ \\
\hline \multirow[t]{3}{*}{$\begin{array}{l}\text { Pre- } \\
\text { Test }\end{array}$} & $\begin{array}{l}\text { Experime } \\
\text { ntal }\end{array}$ & 45 & & 41.33 & 8.555 & & \\
\hline & Control & 40 & & 43.25 & 8.590 & 0.77 & $\begin{array}{l}0.12 \\
\text { NS }\end{array}$ \\
\hline & & & 83 & & & & \\
\hline \multirow[t]{2}{*}{$\begin{array}{l}\text { Post- } \\
\text { Test }\end{array}$} & $\begin{array}{l}\text { Experime } \\
\text { ntal }\end{array}$ & 45 & & 70.22 & 10.44 & 0.89 & $\begin{array}{l}0.00 \\
*\end{array}$ \\
\hline & Control & 40 & & 61.88 & 9.59 & & \\
\hline
\end{tabular}

* - Significant at 0.05 ,

Table 4 shows the posttest result of the experimental and control group $(\mathrm{t}$-value $=0.89, \mathrm{df}=83, \mathrm{P}$-value $=$ $0.00 \& \mathrm{P}<0.05)$ was significant, as such hypothesis one was rejected. This implies that the use of Improvised Instructional Materials to teach students Mitosis in Biology has enhanced their academic achievement compared to those taught using conventional teaching method.

$\mathrm{Ho}_{2}$ : There is no significant difference in the mean achievement score of Biology students

taught the concept of Mitosis with improvised instructional material (improvised phases of mitosis) and those taught with conventional instructional method based on

gender. To test this formulated hypothesis, independent t-test was used, and the analysis presented in Table 5 . 
Table 5:t-test Analysis of Mean Achievement Scores of Male and Female Students in Experimental Group

\begin{tabular}{|c|c|c|c|c|c|c|c|}
\hline Group & $\begin{array}{l}\text { Gen } \\
\text { der }\end{array}$ & $\mathbf{N}$ & Df & $\overline{\boldsymbol{X}}$ & SD & $\begin{array}{l}\text { t- } \\
\text { value }\end{array}$ & $\begin{array}{l}\text { P- } \\
\text { value }\end{array}$ \\
\hline \multirow{3}{*}{$\begin{array}{l}\text { Post- } \\
\text { Test }\end{array}$} & $\begin{array}{l}\text { Mal } \\
\mathrm{e}\end{array}$ & 24 & & 66.65 & 10.98 & & \\
\hline & & & 43 & & & 0.82 & $\underset{S}{0.56^{\mathrm{N}}}$ \\
\hline & $\begin{array}{l}\text { Fem } \\
\text { ale }\end{array}$ & 21 & & 67.05 & 10.73 & & \\
\hline
\end{tabular}

NSNot Significance at 0.05 .

Table 5 shows the $t$ - test analysis of mean achievement scores of male and female and the tvalue was 0.82 and the $P$-value was 0.56 , this means it was not significant as such hypothesis two was accepted. This implies that using Improvised Instructional Materials to teach students Mitosis in Biology enhanced gender achievement equally.

\section{Summary of Findings}

1. This revealed that improvised instructional materials enhanced students' achievement better than conventional teaching method.

2. This revealed that improvised instructional materials enhanced male and female students' achievement equally.

\section{DISCUSSION}

This study revealed that improvised instructional materials enhanced students' achievement better than conventional instructional method. This finding is in agreement with the finding of Adeyemi and Olayeye (2010)who investigated the effect of student involvement in production of instructional material on their academic achievement in Biology and they reported a significant difference between students taught biology without instructional materials and those taught using locally produced instructional materials. Similarly, the finding agrees with the finding of Oladejo, Olosunde, Ojebisi and Isola (2011) who carried out a study on instructional materials and students' academic achievement in physics. They reported that, students taught with improvised instructional materials obtained the highest achievement score at posttest, followed by those with standard instructional materials, while the control group score the lowest. The finding shows that there is significant difference in the achievement scores of students taught using improvised instructional materials, standard materials, and conventional method. This is because the improvised instructional materials used on the students of the Experimental Group has enhanced the students' level of comprehension of the concept of mitosis.
The study also revealed that improvised instructional materials enhanced both male and female students' achievement better but there was no significant difference between the two groups. This finding is in line with the findings of Ogunleye and Babajide (2011) who found that there is no significant difference between the performance of male and females. But, the finding was in disagreement with the findings of Adeyemi and Olayeye (2010) who carried out a study on effect of student involvement in the production of instructional materials on academic achievement in biology and reported a significant difference in the posttest achievement scores of male and female students taught biology using instructional materials.

Based on the findings of this study, it is concluded that students taught Mitosis with the use of improvised instructional materials (experimental group) achieved better than their counterpart taught same concept (Mitosis) using the conventional method. There was no significant difference in gender achievement of students taught Mitosis with improvised instructional materials. Therefore, the use of improvised instructional materials improved the teaching and learning of Mitosis.

\section{Conclusion}

The biology teacher should make use of different and relevant local materials for improvisation so long as they are relevant to the content to be taught.

Biology teachers should be resourceful in material selection and planning in order to reduce the cost of improvisation and maintenance of improvised instructional materials.

Government should try to provide funds to secondary school biology teachers to be enable to improvised the necessary instructional materials for teaching

Stakeholders in education should organised in service training, seminar, workshops conference on how to improvise the instructional materials for biology teachers so as to bring about effective and meaningful teaching and learning..

\section{REFERENCES}

Abdulrahman, B.O. (2016). The influence of gender on secondary school student's academic performance in south west, Nigeria. Journal of social science, 31 (1): 93-98.

Adeyemi, A. and Olaleye, A. (2010). effect of student`s involvement in the production of instructional materials on their academic achievement in biology. Retrieved Nigeria education to attain its 
past glory (WWW. Nigerianfinder.com) may 10,2017 .

Ahmed, k. (2010). Functionality of the teaching of secondary school Biology in a period of global preparation strategies for salvage. Ibadan. TDEPublisher.

Ali, F. A. (2012) the impact of instructional materials on the academic performance of primary school pupils in Maikurdi LGA of Benue State. Contemporary issues in education. Markurdi destiny ventures.

Awolaju, B. A. (2015). Instructional materials as correlation of students' academic performance in biology in senior secondary schools as correlates of students academic performance in biology in senior secondary schools in Osun State. International journal of information \& education technology 6 (9), September 2016.

Eze, P.I. (2012). Improvisation of educational resource as means of achieving education for All. In Nogbonnaya, R. Akpan \& Ajaegbo, D. (2012). Education All. The journey so far, 123-138.

Federal Republic of Nigeria, (2009). National policy on education Abuja: NERDC press.

Isola, O.M. (2010). Effects of standardized and improvised instructional materials on academic achievements in secondary school physics. M.e.d thesis, university of Ibadan, Ibadan.

Lawal, F.K. (2014). Biology teachers' perception of senior secondary school Biology curriculum and the need for reform. STAN $52^{\text {nd }}$ annual conference.

Ogunleye, B.O and Babajide, F.T. (2011). Commitment to science and gender as determinants of student achievement and practical skills in physics. Journal of the science teachers' association of Nigeria, 1 (46) 125-135.

Oladejo, M.A., Olosunde, G.R., Ojebisi, A.O.\& Isola, O.M. (2011). Instructional materials and student academic achievement in physics. European Journal of Education (4) 1-12

Olumorin, C. O, Yusuf, A., Ajidagba, U. A. \& Jekayinta, A. A. (2010). Development of instructional materials from local sources, Asian journal of information Technology 9 (2) 107- 110.

Sarigin, T. R. (2010). Modern biology for senior secondary school p.2 AFP plc Nigeria.

Sheldon, I. (2011). Educational management instruction in context for improvisation. London academic press, London.

Umoru, S. E. (2016). Effect of laboratory method on students' achievement. Journal of research and method in education (31) 1-12
WAEC, (2016). The West African Examinations Council Chief Examiners' Report 